ROCZNIKI HUMANISTYCZNE

Tom LXIX, zeszyt 3 - 2021

DOI: http://doi.org/10.18290/rh21693-4

WOJCIECH KOPEK

\author{
„...DUM CAPITOLIUM SCANDET \\ CUM TACITA VIRGINE PONTIFEX". \\ FUNKCJA FIGURY POCHODU W PIEŚNI III, 30 \\ EXEGI MONUMENTUM HORACEGO
}

Carmina Kwintusa Horacjusza Flakka jako jednolity zbiór stanowią niewątpliwy fundament światowej liryki, zapewniając, mimo upływu czasu, niewyczerpane źródło literackich inspiracji i ustanawiając niedościgły wzorzec dla poetyckiego współzawodnictwa. Dzieło to, będąc wytworem nowej kultury wydawniczej okresu augustowskiego, kiedy „księga” (liber) stała się osobną jednostką z celowym układem utworów, wyraźnym wstępem-dedykacją, epilogiem i wewnętrznym reżimem, opartym na układzie tematycznym (Fantham 63-67), nie jest jednak monolitem, poszczególne pieśni, przy swoich intertekstualnych powiązaniach, zachowują dużą autonomiczność. Wśród nich trudno byłoby wskazać odę bardziej spopularyzowaną, nie tylko w literaturze, ale też w historii literatury poprzez podręczniki szkolne, niż pieśń III, 30 Exegi monumentum, $\mathrm{z}$ jej centralnym, potężnie wybrzmiewającym w dwudziestym pierwszym wieku od śmierci Horacego, motywem non omnis moriar.

Waga tego utworu ujawnia się jednak najpełniej właśnie w miejscu, jakie wyznaczył mu w układzie ód sam Horacy, jest bowiem epilogiem księgi III, a zbiór trzech pierwszych ksiąg Carmina można traktować jako zamkniętą całość (Günther 211-221). Dlatego też analiza tekstu zostanie przeprowadzona na płaszczyźnie powiązań intertekstualnych, z uwzględnieniem jednak dystynktywnych cech pieśni. Jej celem będzie semiotyczna analiza motywu „pochodu tanecznego” w kontekście toposu spotkania z bóstwem w liryce Horacjańskiej (Hor. Carm. III, 30, 7-14) ${ }^{1}$.

Dr WoJCIECH KoPeK - Katolicki Uniwersytet Lubelski Jana Pawła II, Instytut Literaturoznawstwa, Katedra Filologii Łacińskiej; adres do korespondencji: Al. Racławickie 14, 20-950 Lublin; e-mail: quidtibivis@wp.pl; ORCID: https://orcid.org/0000-0002-9786-650X.

${ }^{1} \mathrm{~W}$ artykule pominę kwestię pierwszeństwa i oryginalności Horacego w literaturze łacińskiej, 
Postawienie takiego problemu wymaga metodologicznego eklektyzmu, ponieważ poetycki obraz ,pochodu tanecznego" czerpie z form rytualnych, obecnych w religii i życiu publicznym starożytnych. Wymaga więc odwołania się do badań z zakresu antropologii, socjologii i historii religii starożytnych jako punktu odniesienia dla uporządkowania możliwych systemów znaków, których realizacją - w myśl semiotycznej definicji tekstu (Żółkiewski, Przedmowa 28) - jest oda III, 30 (oraz inne przytoczone pieśni). Sama jednak rekonstrukcja danego obrazu nie zawsze jest jednoznaczna ze zrozumieniem jego znaczenia oraz funkcji. Stąd też w analizie wykorzystanych motywów pomocne jest spojrzenie $\mathrm{z}$ punktu widzenia metatekstu rozumianego jako forma autorefleksji świadomego twórcy nad danym tekstem, sygnalizowanej w tymże tekście w sposób mniej lub bardziej ukryty (Mojsik 222-224; Danielewicz 46-62). Utwór tego typu staje się zatem „obiektem semantycznie dwupoziomowym", utworem, który realizuje swój temat główny, w wypadku ody III, 30 byłby to motyw non omnis moriar, oraz temat dodatkowy, stanowiący komentarz natury teoretycznoliterackiej, nie tyle do jednostkowego tekstu, ile do procesu twórczego (Bakuła 33). Takie ujęcie skłania do powrotu do samej definicji tekstu, gdyż metadzieło, będąc „uporządkowaną sekwencją znaków" (Żółkiewski, Przedmowa 28), samo może być traktowane w kategoriach znaku, a raczej „metaznaku”, który nie odnosi się wprost do rzeczywistości ze względu na zależność od medium w postaci metatekstu (Bakuła 32). Chociaż przywołana definicja dotyczy relacji prototekst-metatekst (np. parodia), jak sądzę, może być użyta do uwypuklenia relacji między motywem nieśmiertelności twórcy a toposem spotkania z bóstwem (bóstwem opiekuńczym poezji), który odnosi się do problematyki teoretycznoliterackiej. Przy tym w taki sposób pojęty topos będzie traktowany jako odrębny byt - tekst kultury (Żółkiewski, Nauka 75-85; Żyłko 192-204).

O tym, jak istotny jest obraz pochodu tanecznego, świadczy umieszczenie go w odzie I, 1 Maecenas atavis. Jako utwór programowy pieśń ta formułuje szereg podstawowych elementów, które mają przedstawić odbiorcy zasady rządzące oddanym do jego dyspozycji zbiorem (Nisbet i Hubbard 1-3). Do

stanowiącą dużą część filologicznej problematyki wyrastającej wokół ody III, 30 (Knapp, The Orginality 251-260; Knapp, The Orginality II 299-307; Otis 185-206; Nisbet i Rudd 375). 
podstawowych należy natchnienie, otrzymane od Dionizosa/Bakchusa, w postaci uwieńczenia poety bluszczem (w. 29-30): „Me doctarum hederae praemia frontium / dis miscent superis", a co za tym idzie - przekroczenie przezeń wymiaru ludzkiego i połączenie z bóstwami w thiasos ( $\theta i ́ \alpha \sigma o \zeta)$ Bakchusa, w którym w chłodnych, świętych gajach uczestniczy w korowodach Nimf i Satyrów (w. 30-32): „me gelidum nemus / Nympharumque leves cum Satyris chori / secernunt populo".

Na uwagę zasługuje kompozycja tekstu tak na poziomie warstwy znaczeniowej, jak i brzmieniowej. Kluczowe w obrazie korowodu jest znaczenie czasownika miscere - mieszać, zmieszać. Leksem w podstawowym znaczeniu odnosi się do mieszania i łączenia w jednolitą substancję różnorodnych składników (szczególnie płynnych), dalej zaś łączenia ludzi w grupy (Nisbet i Hubbard 13), a nawet powodowania zamieszania (Gardin Dumesnil 173); ten zakres znaczeniowy odzwierciedla szyk wyrazów w jednostkach metrycznych. Nie organizuje ich bowiem szyk zwyczajowy, lecz hiperbaton $\mathrm{z}$ anaforą zaimka me, co podkreśla zanurzenie podmiotu $\mathrm{w}$ towarzyszącym mu chaosie tanecznego korowodu. W przytoczonych powyżej wersach figura ta realizuje się w rozbiciu frazy doctarum frontium, a jeszcze wyraźniej w rozdzieleniu, można powiedzieć technicznego terminu, di superi przez miscere. Podobnie skomponowane zostały wersy 30-32, w których można dostrzec przeplatanie się przydawek do chorus oraz rozdzielenie gramatycznie związanego z Nympharum ablatiwu towarzysza cum Satyris (por. Nisbet 135-154). Zwielokrotnienie hiperbaton w kompozycji danego passusu prowadzi do mixtura

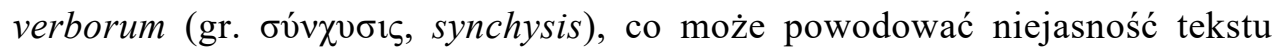
(obscuritas) (Lausberg 398-399 § 716), lecz w wypadku ody I, 1 staje się werbalnym i rytmicznym odpowiednikiem skonstruowanego obrazu poetyckiego.

Nie jest to jednak obraz frywolny, wydaje się bowiem bliski przeżyciu

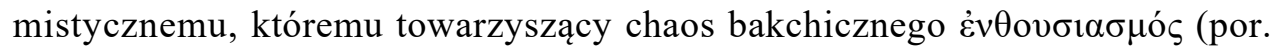
Carm. II, 19 Bacchum in remotis; Carm. III, 25 Quo me, Bacche, rapis) nadaje wymiar sakralny (por. Bonnechere 153-155). Podkreśla go nie tylko słownictwo związane z wymiarem kultowym, jak nemus i chorus, ale przede wszystkim motyw oddzielenia od ludzi (secernunt populo), stanowiący istotną część Horacjańskiej koncepcji kapłaństwa poety (Carm. III, 1, 1-4):

Odi profanum volgus et arceo.

Favete linguis: carmina non prius audita Musarum sacerdos virginibus puerisque canto. 
W twórczości Wenuzyjczyka secernere ma wyraźną funkcję rozgraniczania między antonimami; w takim sensie pojawia się w satyrze I, 6, 63: „qui turpi secernis honestum”. Secreta loca są też ulubionym miejscem przebywania natchnionego poety, satyrycznie przedstawionego w Ars poetica (w. 298). Owo oddzielenie od społeczności, bliskie doświadczanie bóstwa w świętym gaju stanowi element wtajemniczenia podmiotu w misterium dionizyjskie, które staje się metaforą poezji. Secernere oraz secretum mają wymiar misteryjny, o czym świadczy cytat z (późniejszego, co prawda, autora) Tacyta (Germ. 9):

Ceterum nec cohibere parietibus deos neque in ullam humani oris speciem adsimulare ex magnitudine caelestium arbitrantur: lucos ac nemora consecrant deorumque nominibus appellant secretum illud, quod sola reverentia vident.

Stąd właśnie wszyscy poeci kochali gaje i uciekali z miasta (Hor. Epist. II, 2, 77-78):

Scriptorum chorus omnis amat nemus et fugit urbem, rite cliens Bacchi somno gaudentis et umbra

Właśnie taki efekt zanurzenia $\mathrm{w}$ atmosferze świętego gaju daje spotkanie z Muzą w odzie do Kalliope (III, 4, 5-8):

Auditis? An me ludit amabilis

insania? Audire et videor pios

errare per lucos, amoenae

quos et aquae subeunt et aurae.

Pomimo że Muzy są odrębnym od Dionizosa elementem świata poetyckiego, motywowi spotkania z bóstwem towarzyszy niezwykle podobna aura tajemniczości i wtajemniczenia, które odrywa podmiot-poetę od otoczenia i przenosi go w niedostępne dla zwykłych śmiertelników miejsce, właściwie gdzieś poza przestrzeń i czas.

Uprzedzając analizę ody III, 25 Quo me, Bacche, rapis, już na tym etapie warto zwrócić uwagę na zawarty w niej obraz przyrody jako przestrzeni, do której został porwany podmiot (w. 3-6):

Quae nemora aut quos agor in specus velox mente nova? Quibus antris egregii Caesaris audiar aeternum meditans decus stellis inserere et consilio Iovis? 
Motywy są stałe: gaj i jaskinia. Należy jednak zwrócić uwagę, że w pieśni Horacy kładzie na nie specjalny nacisk poprzez ich częstotliwość; w wersach 13-15 powraca do tych samych konwencjonalnych motywów, ale wzbogaca je odniesieniami do miejsc rzeczywistych (w. 10-12). Konstruuje to symboliczną geografię poetycką, w której nazwy geograficzne, Hebrus, Tracja, Rodopy, zostają otoczone przez określenia miejsc świętych, wyjętych z realnej przestrzeni. Nie powoduje to ich rozdzielenia, lecz sprawia, że tym wyraźniej zaznacza się przenikanie sfer boskiej i ludzkiej w obrębie przestrzeni poetyckiej. Gaj (nemus) i jaskinia/góry (antrum) nie tylko realizują topikę locus amoenus, lecz stanowią realną przestrzeń dla poetyckich bytów. Przejście od konkretnego miejsca do locus communis stanowi wchłonięcie zewnętrznej, ekstatycznej przestrzeni bakchicznej przez introwertyczną, (auto)refleksyjną, wewnętrzną przestrzeń twórcy.

Nie jest w tym kontekście istotne ani to, czy między pius lucus a gelidum nemus zachodzi pełna ekwiwalencja czy też wskazują one na różne żywioły, apolliński i dionizyjski, ani to, że spotkanie z Muzą w odzie III, 4 jest zdecydowanie bardziej intymne; przebiegając w relacji poeta-bóstwo, podczas gdy w kontakcie z orszakiem Dionizosa poeta ma do czynienia ze zbiorowością. Ważne jest natomiast to, że zarówno „dające się pokochać szaleństwo”, jak i zatracenie w tańcu realizują się jako forma przejścia między wymiarem ludzkim a boskim, przestrzenią realną i liminalną.

W ten sposób podmiot ody I, 1 to nie tylko natchniony, erudycyjny poeta (doctus; por. Nisbet i Hubbard 13), to także mystes, wtajemniczony w (poetyckie) misteria Dionizosa, który w kolejnych wersach sięgnie po ostateczny, kapłański tytuł-vates (w. 32-36).

Pomijając bogactwo znaczeń, jakie oda niesie dla zrozumienia Horacjańskiej koncepcji poezji, należy jednak wskazać na podobieństwo motywu pochodu bakchicznego do toposu spotkania z bóstwem, który w poezji greckiej można uznać za jeden $\mathrm{z}$ istotniejszych sposobów metapoetyckiej kreacji odautorskiego podmiotu-poety.

Spotkanie $\mathrm{z}$ bóstwem, rozumiane jako forma rytuału inicjacji w wymiarze antropologicznym i metapoetyckim, dla okresu archaicznego i klasycznego literatury greckiej opisał Tomasz Mojsik. W analizie oparł się na modelu nadrzędnym: 1) separacja/oddzielenie - jednostka rytualnie zostaje pozbawiona dawnego miejsca w strukturze społecznej; 2) faza liminalna, marginalizacja - okres przejściowy, w którym jednostka już nie posiada cech przeszłych, ale nie zyskała jeszcze cech przyszłych; 3) włączenie - ustanowienie nowej przynależności, praw i obowiązków jednostki w grupie (van Gennep 36-37; Mojsik 246). 
W odniesieniu do tego schematu badacz, poprzez analizę spotkań z bóstwami w dziełach lub świadectw zachowanych w tradycji biograficznej twórców greckich (oraz Enniusza), wyznaczył dla toposu spotkania z bóstwem sześć stałych elementów: 1) czas - południe, noc, sen, bezczasowość, brak określenia czasu; 2) miejsce - odludzie, obrzeża, winnica, góry, wybrzeże, jaskinia, pobocze drogi między dwoma miejscowościami; przestrzeń, gdzie spotykają się sfery - boska, ludzka i świata natury; 3) bohater - niedojrzały, o niesprecyzowanej jeszcze roli w społeczności, często na pograniczu świata cywilizacji i natury - np. pastuszek; 4) spotkane istoty - Muzy, Dionizos, pszczoły, inni bogowie (jako grupa), personifikacje, bogowie związani z danym gatunkiem literackim, bohaterowie literaccy; 5) charakter spotkania - może prowadzić do fizycznego i/lub psychicznego upokorzenia bohatera i do fizjologicznych zmian (ślepota, chromość, szaleństwo); 6) dary - przemieniony poeta otrzymuje dar pieśni i głosu - sztuki poetyckiej - oraz wiedzę, której nie posiadał wcześniej. Kończą one symboliczną inicjację i stanowią konieczny element nowego miejsca w społeczności. Może towarzyszyć im artefakt: instrument, różdżka itp. (Mojsik 242-246).

Wyznaczony wzorzec skłonił badacza do sformułowania wniosku, że istniał w literaturze antycznej „wspólny, znany i poetom, i większości odbiorców, zbiór wyobrażeń dotyczących roli i funkcji poety" (255). Niemniej w miarę upływu czasu część materiału źródłowego stanowi wyraźną, świadomą grę z podstawowym, epickim wzorcem (255).

Powyższy schemat można zaadaptować do analizy struktury ody I, 1 . Byłyby to zatem: 1) czas - w odzie nieokreślone praesens, dwukrotnie mocno zaznaczone wyrażeniami oznaczającymi „bezczasowe” istnienie: sunt quos (w. 3), est qui (w. 19). Warunkowe przesunięcie ku przyszłości w zakończeniu pieśni należy już do okresu poinicjacyjnego; 2) miejsce - gelidum nemus - święty gaj, przestrzeń liminalna; 3 ) bohater - Horacjański podmiot-poeta nie jest co prawda młodym pasterzem, ale dedykując zbiór patronowi, stawia się w roli klienta. Przywołuje to już ustaloną i funkcjonującą kontekstualnie w satyrach poetycką biografię syna wyzwoleńca (Sat. I, 6, 6 i 4564), co wskazuje na specyficzny aspekt osoby z ,nizin społecznych”. Motyw ten był obecny $w$ tradycji biograficznej Ezopa, niewolnika niemowy (same teksty pochodzą z I, w. n.e., ale tradycja jest znacznie starsza - V w. p.n.e.; Mojsik 241-242). Ten aspekt toposu dostrzegalny jest w odzie III, 30, 12-14, w której dopełnia się przemiana poety: ex humili potens. Obecnie jednak zestawienie z szeregiem zawodów i zajęć rekreacyjnych w rozbudowanej enumeracji (w. 3-29) ukazuje go jako osobę o odrębnym od reszty społecz- 
ności powołaniu (na granicy otium i negotium). Zakończenie ody w zdaniu warunkowym podkreśla, że jeszcze tego powołania nie wypełnił, ponieważ wciąż oczekuje na przyjęcie do nowej grupy - wieszczów lirycznych. Oznacza to, że podmiot ody wciąż znajduje się w czasie i przestrzeni granicznej. Współgra to z punktem 4), gdyż spotkane istoty przynależą właśnie

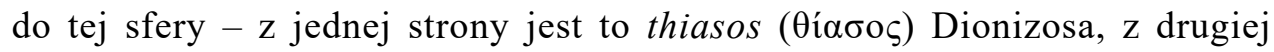
Muzy - Euterpe i Polihymnia. Najtrudniej uchwytny jest punkt 5) - charakter spotkania. Wydaje się, że jest realizowany przede wszystkim poprzez umieszczenie podmiotu jako człowieka $\mathrm{w}$ bakchicznym korowodzie, co sugeruje motyw poetyckiego szaleństwa, współgrający $\mathrm{z}$ terminem vates. Samemu momentowi spotkania $\mathrm{z}$ bóstwem jako formie porwania i opano-

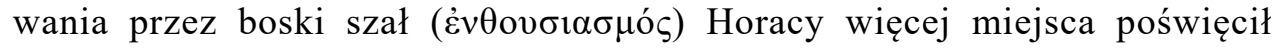
w Carm. III, 25 Quo me, Bacche, rapis. Natomiast we wstępie do ód mocno wybrzmiał motyw 6) - boskiego daru, który potwierdza dokonującą się przemianę. Realizowany jest dwufazowo. W pierwszej stanowi go wieniec z bluszczu: „Me doctarum hederae praemia frontium / dis miscent superis”. Leksem praemium można interpretować zarówno w kontekście poprzednich wersów o myśliwym jako zdobycz, jak i w szerszym kontekście jako oznakę wykonywanego ,zawodu”. Bluszcz jest zatem z jednej strony artefaktem określającym miejsce w społeczności, z drugiej - boskim darem, który z niej poetę wyklucza. Podobnie funkcjonuje przymiotnik doctus. Może on oznaczać biegłość w sztuce poetyckiej (ars, techne), ale także głębszą wiedzę, jaką odznaczają się poeci (gr. бo甲ós) (Nisbet i Hubbard 13). Wieniec nie jest jednak w pełni symbolem zewnętrznym, ponieważ przynależy do liminalnej sfery korowodu, oddzielonej od społeczności. Nie może być widomą, a jedynie symboliczną oznaką nowej funkcji poety. W fazie drugiej, paralelnie do rydwanu i palmy pierwszeństwa otrzymanej przez sportowca, ojcowskiego pługa rolnika czy statku kupieckiego, będą funkcjonowały dopiero tibia i barbiton - dary Muz. To dwufazowe rozbicie na sferę szaleństwa/natchnienia i następującą po nim sferę pieśni, rozumianej jako osobny, odrębny od natchnienia, wynik działań twórczych w postaci utworu (istniejącego zarówno w formie oralnej, jak i w postaci tekstu), można ująć w kategoriach teorii Neoptolemosa z Parion, istotnego źródła Horacjańskiej koncepcji

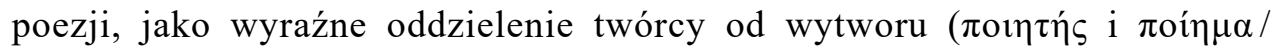

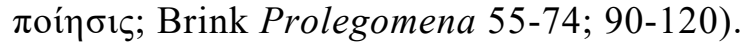

Łącznie powyższe motywy są oznaką inicjacji; poeta otrzymuje zewnętrzny artefakt, symbol swojego powołania, ale przede wszystkim dokonuje się w nim wewnętrzna przemiana, zyskuje wiedzę (tajemną) konieczną do two- 
rzenia poezji. Wydaje się więc rzeczą nieprzypadkową, że - na wzór Hezjoda - we wstępie do pierwszej księgi ód, będącym wstępem do całości zbioru i przejściem do nowego gatunku literackiego po epodach i satyrach, Horacy posłużył się inicjacyjnym toposem spotkania z bóstwem.

\section{CARM. III, 25 QUO ME, BACCHE, RAPIS}

O „bakchiczności” tej konkretnej realizacji toposu decyduje specyficzna pozycja, jaką zajmuje poeta w orszaku Dionizosa, oraz obecny w pieśniach motyw poetyckiego szaleństwa. Najwyraźniej ukazany został on w Carm. III, 25 Quo me, Bacche, rapis. Nisbet i Rudd sytuują ten tekst w kontekście szału opisanego przez Platona w Ionie, Obronie 22a-c, Menonie 99c-e i Fajdrosie 245a, zaznaczając przy tym, że filozof z nutą ironii łączył wyrafinowany poetycki szał z menadyzmem, odróżniając go od inspiracji płynącej od Muz (296). Dla uproszczenia zatem przyjmę, że motyw ten w obrębie ód, z zachowaniem Horacjańskiego dystansu i autoironii, realizuje się w ukazanej w Carm. III, 4 Descende caelo koncepcji amabilis insania (w. 5-8) (por. też ingenium, mens divinior w Sat. I, 4, 39-44).

Już pierwsze wersy Carm. III, 25 wyznaczają podstawowy, funkcjonalny element utworu:

Quo me, Bacche, rapis tui

plenum? Quae nemora aut quos agor in specus velox mente nova?

Szał bakchiczny pojawia się nagle, bez ostrzeżenia. Towarzyszy mu okrzyk zdezorientowanego podmiotu, wyrwanego ze znanej przestrzeni - quo me rapis? i rzuconego w przestrzeń graniczną: święty gaj - nemus oraz grotę specus i antrum (w. 4), powszechnie stanowiącą miejsce święte. Motyw porwania łączy się $\mathrm{z}$ przemianą wewnętrzną - velox mente nova. Nisbet i Rudd rozumieli frazę jako odniesienie do religijnego uniesienia Menady (zob. w. 13-16), stanowiącego sedno metafory literackiego szału (300-301).

Początkowy motyw, na poziomie poetyckiego obrazowania, można rozumieć bardzo dosłownie jako porwanie przez bóstwo szczególnej dlań osoby. Był on popularny w sztuce antycznej, by wspomnieć jedynie sceny porwania Tithonosa przez Eos czy Ganimedesa przez Zeusa w rzeźbie i malarstwie wazowym. Ciekawym przykładem są też rekonstrukcje zachodniego i wschodniego akroterionu Świątyni Ateńczyków na Delos, które analogicznie ukazy- 
wały sceny porwania Kefalosa przez Eos i Orejtyi przez Boreasza (Bernhard 528-529). Co ciekawe, konstrukcja wszystkich przedstawień jest niemal identyczna. Postaci są splecione w gwałtownym ruchu, w którym porywający, unosząc porywanego w przestrzeń ponadziemską, jedną ręką chwyta go za przedramię, drugą natomiast oplata wokół jego pleców bądź ramion. Motyw raptus, w którym przeplata się przemoc i erotyka, nie jest obcy również literaturze rzymskiej, by wspomnieć choćby porwanie Ganimedesa (Hor. Carm. III, 20; Cic. Tusc. I, 26, 65).

Analizując grecką epigramatykę nagrobną, Andrzej Wypustek wskazał na szereg czasowników oznaczających porywanie: $\dot{\alpha} \rho \pi \alpha ́ \zeta \omega, \ddot{\alpha} \gamma \omega(\kappa \alpha \tau \dot{\gamma} \gamma \omega), \lambda \alpha \mu-$

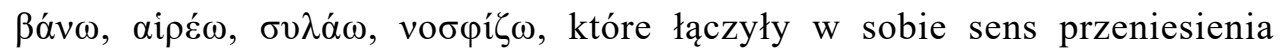
$\mathrm{w}$ inne miejsce $\mathrm{z}$ zastosowaniem przemocy, oscylując nawet $\mathrm{w}$ granicach gwałtu (111-112). Szczególnie interesujący jest leksem $\lambda \alpha \mu \beta \alpha ́ v \omega$, który pojawia się zarówno w kontekście motywu szału, jak i porwania. Herodot w Dziejach, opisując wtajemniczenie scytyjskiego władcy o greckich korzeniach, Skylesa, w kult Dionizosa, w usta jednego z goszczących go w swym mieście Borystenitów włożył skierowane do Scytów słowa (IV, 79, 4):

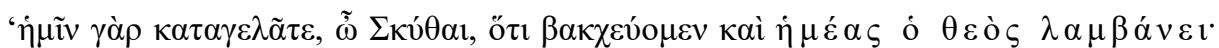

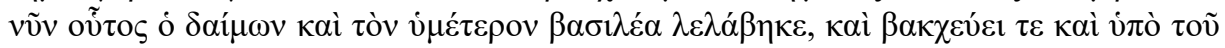
$\theta \varepsilon o \tilde{v} \mu \alpha i ́ v \varepsilon \tau \alpha$. [Podkr. aut.]

Z nas szydzicie, Scytowie, że obchodzimy orgie bakchiczne i że bóg nas og arnia; teraz to bóstwo ogarnęło także waszego króla, więc obchodzi te same orgie i pod wpływem boga szaleje. (Tłum. Seweryn Hammer; podkr. aut.)

Podobnie Platon, analizując w Fajdrosie (245a) rodzaje szaleństwa, o tym zsyłanym przez Muzy pisze:

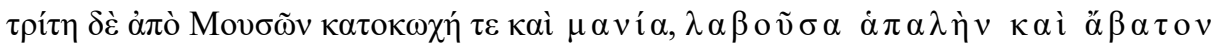

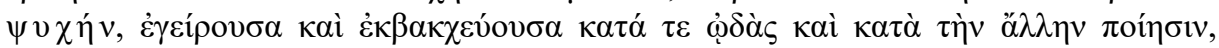

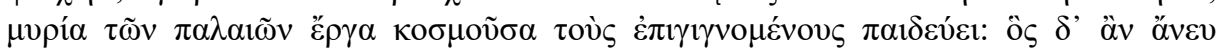

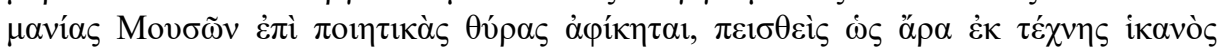

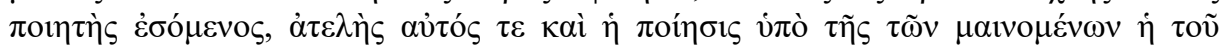

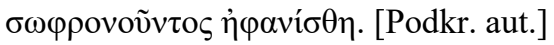

Trzeci od Muz pochodzi szał i natchnienie takie, co młodą, świeżą, czystą duszę porywa, a ona się budzi i wybucha w pieśniach i w innej twórczości artysty, a tysiączne czyny przodków zdobiąc, potomnych wychowuje. Kto bez tego szału Muz do wrót poezji przystępuje, przekonany, że dzięki samej technice będzie wielkim artystą, ten nie ma święceń potrzebnych i twórczość szaleńców zaćmi jego sztukę z rozsądku zrodzoną. (Tłum. Władysław Witwicki; podkr. aut.). 
Horacy zatem spaja dwa motywy: porwania przez bóstwo oraz bakchicznego szału. Dzięki temu porywacz i porwany wchodzą w szczególną relację.

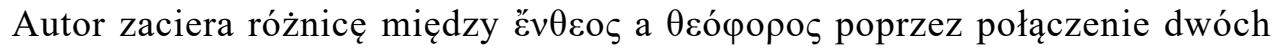
motywów literackich w jedną figurę artystyczną. Pozwala to na zbudowanie metafory porwania-przejścia-inicjacji, z jednoczesnym podkreśleniem metaforyczności podróży w głąb siebie, w misteryjne wtajemniczenie i doświad-

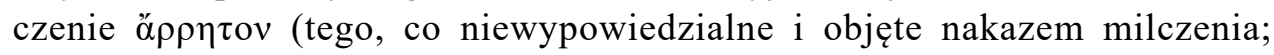
zob. Burkert 192-195): „Dicam insigne, recens, adhuc / indictum ore alio” (w. 7-8). Wplecenie motywu porwania $\mathrm{w}$ topikę szału poetyckiego podkreśla, że podmiot dla Bakchusa jest kimś szczególnym - wybranym przezeń kochankiem-kapłanem. I to właśnie podmiot wysunięty zostaje na pierwszy plan. Bakchus nie porywa kogoś przypadkowego, porywa osobę wyróżniającą się, której chce nadać wyjątkowy status w swym orszaku. Dzięki temu podmiot zostaje porwany do świata bogów i ulega przemianie. Nie jest już nawet wieszczem, kapłanem kultu, staje się herosem, pomniejszym bóstwem, można powiedzieć emanacją samego Dionizosa, który go wypełnia.

Bóstwo wciąż, jak u Platona (Ion 533d-e), stoi na czele przenikniętego jego magnetyczną mocą łańcucha bytów, lecz zmienia się zupełnie optyka nowej figury. Ukazana jest z centralnej pozycji podmiotu-twórcy, który wciąż pozostając transcendentny (z punktu widzenia bóstwa), jednocześnie transcenduje (z punktu widzenia odbiorcy) rzeczywistość. Wykraczając dzięki temu poza funkcję nośnika boskich ( $\mathrm{w}$ sensie: literackich) treści, staje się samym przejściem, łącznikiem działającym w obydwie strony „łańcucha bytów”.

Dotychczasowa platońska linearność zostaje zastąpiona strukturą powiązań o zdefiniowanym centrum (twórca) i siecią relacji „do” oraz „od” punktu centralnego. Poeta opętany przez bóstwo przeradza się jednocześnie w jego wybrańca, zyskując status szczególny w przepływie boskiego natchnienia, nie zaś „narzędziowy”, jak było to w ujęciu Platona. Dzięki temu zdefiniowany przez Horacego poeta liryczny - wieszcz - może przejąć kontrolę nad inspirującym go szaleństwem.

Pomiędzy motywem porwania, rapis (w. 1) oraz agor (w. 2), a pojawieniem się wytworu, dicam (w. 7) i loquar (w. 19), znajduje się bowiem proces twórczy - audiar meditans antris (w. 4-5). Na poziomie języka ta koncepcja spaja się w operowaniu stronami bierną i czynną czasowników oraz zastosowaniem verba deponentia (zob. Kühner 783-784; Pinkster 282-285) jako elementu łączącego. W scenie porwania/opanowania przez bóstwo strona czynna z orzeczeniem rapis, drugoosobowym zwrotem do Bakchusa, i dopełnieniem me, odnoszącym się do podmiotu lirycznego, ustępuje miejsca 
konstrukcji w stronie biernej: „Quae nemora aut quos agor in specus velox mente nova?" (w. 2-3), która sugeruje rozbicie podmiotu lirycznego na obiekt działań i zewnętrznego obserwatora.

Pytanie „Quibus / antris (...) audiar / meditans?” nie stanowi już bezpośredniej reakcji na porwanie, zmienia się czas orzeczenia: agor - czas teraźniejszy, audiar - czas przyszły. Owa modyfikacja skupia się w imiesłowie meditans (w. 5), który stanowi formę czynną (participium praesentis activi) od meditari, verbum deponens, posiadającego w zdecydowanej większości morfologię strony biernej przy znaczeniu strony czynnej. Interesująca jest także wewnętrzna paralela między: „Dicam insigne, recens, adhuc indictum ore alio” (w. 7-8) a stanowiącą jej negatywny odpowiednik frazą: „nil parvum aut humili modo, nil mortale loquar" (w. 17-18). Można powiedzieć, że warstwa językowa ściśle podąża za przemianą samego podmiotu, który od aktualnego stanu porwania (przeżycia traumatycznego), podporządkowania woli Bakchusa (szaleństwa), stopniowo przechodzi do autorefleksji i ostatecznie odzyskuje swoją podmiotowość wraz ze zdobytą wiedzą. Służąc zaś do wyrażenia tejże przemiany, fenomenu niezakorzenionego bezpośrednio w formach leksykalnych, lecz nadbudowanego nad ich morfologią i semantyką, staje się elementem metajęzyka tekstu.

Tworząc utwór metapoetycki, poeta zadbał, aby słownictwo konstruujące świat przedstawiony kojarzyło się odbiorcy z retoryką, która była najbliższa teorii literatury. Nisbet i Rudd w komentarzu do ody wskazują na retoryczną proweniencję rapere i velox, które wiążą się z pojęciem impetus, czyli wpływem wywieranym przez mówcę na odbiorców, porywanych oracją. Pośrednio określają także dytyrambiczną gwałtowność samej ody III, 25 (299-301). Niemniej w twórczości poety znaczenia terminologicznego nabierają także słowa meditari i sequi.

Znaczenie meditari podkreśla list II, 2 (w. 65-86), w którym dojrzały już twórca $z$ dystansem spogląda na dorobek własny i młodszego pokolenia. Nieco zrzędliwy podmiot listu w odpowiedzi na domaganie się odeń nowej twórczości kreuje obraz miasta wrogiego poecie. Przede wszystkim przeszkadza thum znajomych, którzy angażują podmiot w sprawy sądowe lub proszą o ocenę wierszy. Albo, co gorsza, chorują, narażając przyjaciela na długą wędrówkę na drugi koniec Rzymu. Zirytowany już samą myślą podmiot wyobraża sobie taką wędrówkę zgiełkliwą ulicą Wiecznego Miasta, którą konfrontuje z perypatetycką wizją spacerującego myśliciela: „Verum purae sunt plateae, nihil ut meditantibus obstet" (w. 70-71), kończąc wykrzyknieniem: „i nunc et uersus tecum meditare canoros” (w. 86). Meditari 
zatem dopełnione poprzez tecum można rozumieć w kategoriach soliloquium, odbywającego się w specyficznej, wewnętrznej przestrzeni, którą symbolizuje świat dzikiej przyrody - związanej z kultem Bakchusa.

Warto też zwrócić uwagę na to, że meditari jest fenomenem „dźwiękowym”. Podmiot w Carm. III, 25 „daje się słyszeć”: „Quibus antris (...) audiar (...) meditans” (w. 3-5), co dalej rozwija się we frazę „dicam insigne” i „nil loquar” (w. 7 i 18). „Dźwiękowy” obraz utworu-pieśni uzupełnia zastosowany przydomek Bakchantki - Euhiada; pochodząc od epitetu Bakchusa Euhius, personifikuje okrzyk - euoi. Tę korelację dodatkowo wzmacnia to, że wersy 8-16 można uznać za odrębny utwór (z dwukropkiem po „Dicam ... alio”). Byłaby to wewnątrztekstowa reprezentacja właściwego dytyrambu, płynącego z ust natchnionego poety. W ten sposób zostaje wygenerowany wewnętrzny ,świat przedstawiony” z postaciami Euhiady i Bakchusa. A liminalna przestrzeń, ukazana w obrazie miejsc, do których sięga wzrok Euhiady, poprzez jej dźwiękowy wymiar, zostaje utożsamiona z samą pieśnią, i za jej sprawą z poetą. Pojawia się więc pytanie, czy to Bakchus opanował twórcę, czy stało się dokładnie na odwrót?

To pytanie prowadzi do znaczenia motywu „naśladowania bóstwa” - do sequi. W przytoczonym już wcześniej Epist. II, 2, 79-80 Horacy łączył „podążanie po samotnych śladach wieszczów” z canere; obydwie czynności ukazując jako metafory samej twórczości:

tu me inter strepitus nocturnos atque diurnos uis canere et contracta sequi uestigia uatum?

Sequi pojawia się w kilku istotnych miejscach Listu do Pizonów: w. 119120: „Aut famam sequere aut sibi conuenientia finge scriptor”, gdzie skonfrontowano sequi, w znaczeniu naśladownictwa, korzystania $\mathrm{z}$ literackiej tradycji (Brink The 'Ars Poetica' 197-200), z fingere, które można rozumieć jako tworzenie czegoś nowego (Ars 125-130). Po raz kolejny w wersie 240:

Ex noto fictum carmen sequar, ut sibi quiuis speret idem, sudet multum frustraque laboret ausus idem; tantum series iuncturaque pollet, tantum de medio sumptis accedit honoris.

Należy zwrócić uwagę, że przywołany passus funkcjonuje w szerszym kontekście, odnoszącym się do zasady decorum w zakresie relacji między postacią a jej charakterem i językiem, jakim posługuje się na scenie. Horacy wiąże sequi z konwencją jako tkanką literacką oraz horyzontem oczekiwań 
odbiorców o określonych przyzwyczajeniach i preferencjach. Sam czasownik pojawia się także w innych kontekstach, lecz zachowuje swoje najważniejsze znaczenie w określaniu wtórności, hierarchii pierwszeństwa i następstwa (por. Epist. II, 2, 143; Ars 311, 456).

Można zadać także pytanie o relację między sequi a imitari w Horacjańskiej koncepcji literatury. Czy są to wyrażenia synonimiczne, czy też odnoszą się do innych fenomenów? Niestety żaden z nich w utworach Horacego nie pojawia się jako zdefiniowany termin techniczny z zakresu poetyki. Niemniej ich użycie sugeruje, że imitari ma węższy zakres znaczeniowy. O ile sequi można rozumieć jako akceptację ogólnej idei, wejście na określoną drogę rozumowania, o tyle pierwszy odnosi się raczej do naśladowania konkretu, twórców, utworów, elementów rzeczywistości (Por. Sat. I, 4, 21; I, 10, 17; II, 2, 64; II, 3, 186, 308; Epist. II, 1, 207; II, 2, 8; Ars 33, 134, 318).

W Carm. III, 25 jednak to właśnie w sequi, które odpowiada klamrowo rapis, dopełnia się rytuał inicjacji. Wśród badaczy toczyła się dyskusja nad gramatyczną konstrukcją ostatniego zdania ody (Carm. III, 25, 18-20):

\author{
Dulce periculum est, \\ o Lenaee, sequi deum \\ cingentem viridi tempora pampino.
}

$\mathrm{W}$ pierwszym momencie można $\mathrm{w}$ prosty sposób powiązać deum $\mathrm{z}$ cingentem, lecz Nisbet i Rudd argumentują za połączeniem imiesłowu z podmiotem lirycznym tekstu. Zmieniałoby to zasadniczo wymowę passusu; zamiast ukazywać boga wieńczącego skronie poety, byłby on subtelniejszy: „Słodkim jest niebezpieczeństwem, o Leneju, że [ja] oplatając [własne] skronie zielonymi liśćmi latorośli podążam za bogiem”. Badacze przytaczają trzy argumenty na poparcie takiej interpretacji tekstu. Po pierwsze, oda skupia się na postaci podmiotu lirycznego. Po drugie, wskazują na metrum, które sugeruje przerwę na końcu 19 wersu. I wreszcie argumentują, że dla powiązania bóstwa $\mathrm{z}$ cingere konieczna byłaby forma imiesłowu czasu przeszłego dokonanego: cinctum. Cytują z Carm. IV, 8, 34: „ornatus viridi tempora pampino" (Nisbet i Rudd 308-309). W tym sensie za podmiot ostatniego zdania należałoby przyjąć nie samo sequi, lecz całą konstrukcję ACI: [me] cingentem sequi (308-3099). A zatem „słodkim niebezpieczeństwem” jest nie tyle podążanie za bóstwem, ile naśladowanie go poprzez posłużenie się artefaktem przysługującym samemu bóstwu - wieńcem z winnej latorośli. Aby zrozumieć ten gest, wywołujący jednocześnie lęk i wzniosłą przyjemność, należy zestawić go z motywami obecnymi w Carm. I, 1 . 
Opasane bluszczem czoło i skronie uwieńczone winoroślą stają się symbolem wywyższenia porwanego poety i włączenia go w poczet (pomniejszych) bóstw. Wywołujące lęk doświadczenie niewątpliwie ociera się o hybris, przy czym jej ciężar równoważy topos porwania przez bóstwo.

\section{CARM. III, 30 EXEGI MONUMENTUM}

Opierając się na wyżej przedstawionej figurze pochodu (thiasos Bakchusa), a także jej znaczeniu w inicjacyjnym toposie spotkania z bóstwem, można poddać analizie poetycki obraz towarzyszący zagadnieniu wprowadzenia pieśni eolskiej do poezji rzymskiej w Carm. III, 30 Exegi monumentum (w. 6-14):

\footnotetext{
Non omnis moriar multaque pars mei vitabit Libitinam; usque ego postera crescam laude recens, dum Capitolium scandet cum tacita virgine pontifex. Dicar, qua violens obstrepit Aufidus et qua pauper aquae Daunus agrestium regnavit populorum, ex humili potens princeps Aeolium carmen ad Italos deduxisse modos.
}

W analizie zostanie jednak pominięte zagadnienie znakowości i semantycznej funkcji metrum, głównie ze względu na swoją nieuchwytność w badaniach nad semantyką metryki starożytnej (Danielewicz 134). Tym niemniej warto wspomnieć, że asklepiadej mniejszy (w interpretacji chorijambicznej; Jurewicz 38), w jakim skomponowano Carm. III, 30, pojawia się jedynie trzykrotnie w Carmina - także w odach I, 1 i IV, 8. Nie wydaje się przypadkowe, że jedno z najrzadziej reprezentowanych w pieśniach metrów łączy wstęp i epilog pierwszego trójksięgu. Podobnie też w wypadku ód III, 30 i IV, 8 istnieje łącznik tematyczny w postaci ujęcia poezji jako nośnika pamięci. Mimo to wydaje się, że metrum może dostarczyć jedynie poszlak interpretacyjnych, nie decydując apriorycznie o semantyce tekstu, a przynajmniej nie $\mathrm{w}$ takim zakresie, jakby można się tego spodziewać $\mathrm{w}$ poezji jambicznej bądź heksametrycznej (Danielewicz 123-127). Z tego powodu analiza zostanie oparta na kompozycji pieśni i sposobie konstruowania wspomnianych obrazów. 
Pomijając ostatni trójwiersz, tekst spaja kilka czasowników, są to: exegi(usque) crescam - (dum) scandet - (dicar) deduxisse. Realizują one schemat: dokonaność - iteratywność (niedokonaność, zob. Devine i Stephens 79-82) dokonaność („perfektywność”, zob. Chernyukh 245-251). Ruch w tekście ma specyficzny wektor „wzwyż” w czasie i przestrzeni: perennius, altius, crescere (wzrastać, powiększać swój rozmiar), scandere (z akuzatiwem kierunku) oraz zestawienie usque - dum, oznaczające duratywność i współzależność czynności wyrażanych w zdaniu okolicznikowym czasu (Wolanin 746). Ów ruch stanowi doskonałą ramę dla motywu nieśmiertelności i przejawów trwania, będących dlań punktem odniesienia. Obejmuje to porównanie do wytworów rąk ludzkich (posąg i piramidy, jak się wydaje: sztuka i inżynieria; w. 1-2), żywiołów i cyklów natury (w. 3-8) oraz samego Rzymu jako wiecznego tworu politycznego (w. 8-9). Natomiast pełne spojenie tego, co „wciąż dokonujące się" następuje w połączeniu dicar - deduxisse w taki sposób, że trwałe skutki czynności wyrażonej w perfectum stanowią treść zapowiedzianą przez orzeczenie - nieśmiertelną chwałę poety, wynikającą ze zrośnięcia się jego dokonań z kulturą rzymską (jej metaforą jest Kapitol, w. 8-9).

Różnica między deducere a ducere polega na rodzaju czynności. Oddaje to dobitnie relacja między nadrzędnym dicar (w. 10) a bezokolicznikiem czasu przeszłego dokonanego deduxisse (w. 14). Należy zwrócić uwagę, że język łaciński może wyrazić aspekt czynności zasadniczo na dwa sposoby: poprzez odpowiedni czas gramatyczny (aspekt gramatyczny) lub budowę wyrazu (aspekt leksykalny) (Devine i Stephens 56-62). W przypadku deduxisse Horacy wykorzystał obydwie możliwości. O ile jednak czas gramatyczny zależy od konstrukcji syntaktycznej zdania, o tyle relacja między czasownikiem bez prefiksu a czasownikiem z prefiksem jest różnicą semantyczną. W wypadku de-ducere prefiks de wskazuje kierunek „od-do” oraz liniowy rozwój czasu czynności jednorazowej. Efektywny zatem aspekt czynności - doprowadzenia, powiązany z konstrukcją dicar - deduxisse, wskazującą uprzedniość członu drugiego względem pierwszego, określa zakończenie czynności z jednoczesną trwałością skutku. W nawiązaniu do teorii Marca Moensa i Marka Steedmana dotyczącej „atomów czynności” (event nucleus), pojmowanych jako powiązana grupa poszczególnych faz wydarzenia (niejako jedność wielości) (15-28), biorąc pod uwagę całość frazy: „Dicar (...), ex humili potens / princeps Aeolium carmen ad Italos / deduxisse modos", można wskazać, że aspekt efektywny deduxisse współgra z określeniem całościowego wymiaru sytuacji, obejmującego jej fazę wstępną (wyrastanie podmiotu z nizin; Eolia), kulminację przybycia oraz jego 
skutki w postaci połączenia pieśni eolskiej z italską. Współgra to z początkiem ody: „Exegi monumentum” (w. 1) - „doprowadziłem do końca dzieło”, z czasownikiem exigere, będącym złożeniem przedrostka ex- z czasownikiem agere, oznaczającego najogólniej „działać”. Pomiędzy exegi a deduxisse zachodzi zatem analogia tak morfologiczna, jak i gramatyczna w zakresie aspektu dokonanego i czasu przeszłego dokonanego ze skutkiem w nieokreślonej teraźniejszości. Przekłada się to na dość oczywistą analogię między exegi monumentum a deduxisse carmen, która wyjaśnia, czym dokładniej jest ów „pomnik” z wersu pierwszego. Co jednak ciekawe, mniej oczywistym powiązaniem między czasownikami jest ich związanie ze sferą ruchu, działania.

Dynamika tej przemiany została osiągnięta poprzez połączenie ruchu (dziania się), przestrzeni i czasu w cykl, który zarówno w warstwie brzmieniowej (metrum), jak i w zakresie obrazowania poetyckiego odwołuje się do jednostek miary (punktów odniesienia) i - wprowadzonej przez podmiot zasady ich przekraczania, z jej ostatecznym wymiarem $\mathrm{w}$ postaci przekroczenia miary życia, jaką fatum (w rozumieniu moira) wyznaczyło śmiertelnikowi.

$\mathrm{Na}$ uwagę zasługuje sposób, w jaki Horacy wprowadził jednostki miary. Już w pierwszym wersie pojawia się przymiotnik perennius, stopień wyższy od perenne. Zastosowany porównawczo określa on trwałość, lecz można w nim dopatrywać się jeszcze jednej funkcji - miary czasu. W podstawowym sensie określa on bowiem to, co trwa przez cały rok, szczególnie zaś odnosi się do płynącej wody, która nigdy nie zamarza (Nisbet i Rudd 368-369; Gardin Dumesnil 40; Hor. Epist. I, 15, 15). Przywodzi on na myśl motyw Heraklitowej rzeki, kontekstu wprowadzającego upływ czasu i związaną z nim wieczną zmianę. W następnych wersach kontekst czasu i trwania zostaje znacznie rozszerzony. To, co „całoroczne”, jest zastąpione przez „łańcuchy" lat - annorum series. Gardin Dumesnil, omawiając różnice między łacińskimi określeniami czasu, wskazał, że leksem tempus odnosi się do „obiegu w określonej przestrzeni”, stąd też oznacza czas cykliczny, pory roku oraz związaną $\mathrm{z}$ nimi pogodę. $\mathrm{W}$ znaczeniu przenośnym określa też niepowodzenia i przeciwności, ale również właściwy moment, odpowiednią porę, wiążąc się z greckim kaıpós (38). Stąd też fraza fuga temporum nie odnosi odbiorcy jedynie do pośpiesznego biegu pór roku, lecz pojawiających się i odchodzących okazji, do obrazu przemijających kolejno chwil i momentów, przypominając o wymykającej się postaci Kairosa oraz epikurejskiej maksymie carpe diem (por. Prauscello 517-518). 
Trwałość zatem Horacjańskiego dzieła została ukazana nie tylko w zestawieniu ze spiżem; wydaje się bowiem, że istotniejsza część porównania jest usytuowana w ciężarze perennius, dla którego punkt odniesienia stanowi motyw cykliczności przyrody, z wiecznym następstwem śmierci i odradzania się. Perennis to taki, który nie podlega cyklowi, jest niezmienny; unikając śmierci, poeta przezwycięża prawa natury, robiąc pierwszy krok w kierunku nieśmiertelności. W takim ujęciu porównanie nie opiera się na zestawieniu obiektów, monumentum i aes, ponieważ obydwóm przysługuje cecha ,trwałości”, lecz na porównaniu jej stopnia (zob. Devine i Stephens 316-322). Co więcej, poeta ukazuje wytwory rąk ludzkich i materiały, z jakich zostały wykonane, w zmaganiach $\mathrm{z}$ upływem czasu i wpływem pogody, których niszczycielskim wpływom (na próżno) usiłują się przeciwstawić. Inaczej rzecz ma się z dokonaniem poety, które zostało zobrazowane nie tyle w walce z żywiołami i czasem, ile zupełnie poza ich zasięgiem: „edax / impotens - non possit diruere" (w. 3-5). Wydaje się, że piramidy i spiż reprezentują przede wszystkim aspekt solidności i wytrzymałości w semantyce perennius jako przeszkody dla nurtu Heraklitowej rzeki, natomiast dokonanie poetyckie stoi $\mathrm{w}$ szeregu $\mathrm{z}$ nurtem, który nigdy nie zamarza, i wiecznie zieloną rośliną - ucieleśniając to, na co zmiana nie ma wpływu.

Zespolenie $\mathrm{w}$ jednolity sens aspektu trwania i cykliczności wydaje się także rozwiązywać problem, jaki postawili Nisbet i Rudd. Komentatorzy bowiem, skupiając się na relacji perennius do crescere i recens (w. 8), podkreślili jego powiązanie z wegetacją, roślinnością wiecznie zieloną, co zaowocowało pytaniem o logikę stopniowania takiej cechy (Nisbet i Rudd 368-369).

$\mathrm{Na}$ tym jednak nie wyczerpują się funkcjonalne możliwości motywu czasu w tekście ody. Wprowadziwszy bowiem punkt odniesienia w postaci cykliczności przyrody i przekroczywszy tę cykliczność motywem non omnis moriar, poeta konstruuje swoją własną „czasoprzestrzeń” w postaci kultury rzymskiej. I chociaż wydaje się, że w tej nowej przestrzeni czas płynie już linearnie, nie jest on jednak całkowicie pozbawiony elementu „cyklicznego”.

Początek nowego czasu jako otwarcie cyklu, który zawsze pozostanie w pierwszej fazie wzrostu, następuje w w. 7-8: „usque ego postera / crescam laude recens". Zarówno crescere, jak i recens odnoszą się do sfery wzrostu roślin, ale ich połączenie wskazuje na moment rozwijania się pączka (Hor. Carm. III, 27, 43). Ta początkowa faza cyklu natury w odzie będzie się jedynie „potęgowała” czy też „,zwielokrotniała”; nie nastąpi już żadna inna faza, ponieważ cykliczność została przełamana. Przestały też obowiązywać stare miary czasu, a na ich miejsce Horacy wprowadził nową - ritus. 
Pomijając zagadnienie ukonkretnienia ceremonii w w. 8-9, szeroko dyskutowane w literaturze przedmiotu (Nisbet i Rudd 337), należy podkreślić, że Horacy nie podał szczegółów uściślających, o jaką uroczystość mogło chodzić. Funkcją motywu jest bowiem wprowadzenie do tekstu nie konkretnej ceremonii, lecz szerszego zwyczaju, który oprócz sensu religijnego obejmowałby także tradycję i kulturę, również w wymiarze państwowym. Znajduje to swój wyraz w figurze Kapitolu (373). Powiązanie motywów nieśmiertelności poety z rzymską państwowością zbliża odę III, 30 do pieśni III, 25. Jak w Exegi monumentum o nieśmiertelności poety decyduje wieczność Rzymu, tak w Quo me, Bacche, rapis spaja się ona z motywem wiecznej chwały Augusta (w. 3-6):

\author{
Quibus \\ antris egregii Caesaris audiar \\ aeternum meditans decus \\ stellis inserere et consilio Iovis?
}

Staje się ona więc gwarantem wieczności twórcy, ponieważ nie może zaistnieć w oderwaniu od poetyckiego przekazu, o czym świadczą ody IV, 8 i IV, 9. Nie jest to jednak jedynie rekonstrukcja motywu epickiego; w obydwóch sytuacjach podmiot-poeta występuje w roli kapłańskiej, a nawet przekracza ją dzięki motywowi porwania przez bóstwo w pieśni III, 25 oraz motywowi nieśmiertelności w III, 30. Umożliwiając wejście do panteonu, sam do niego trafia. Trudno w tym momencie nie zatrzymać się nad profetycznym wymiarem tej figury $\mathrm{w}$ perspektywie wyboru poety na twórcę Carmen seculare.

Ritus spaja zatem oficjalną rzymską religię oraz państwowość w nierozłączną całość, o sile jednak tego motywu decyduje fakt, że swoją trwałość zawdzięcza towarzyszącej mu powtarzalności (Maisonneuve 10-13). W tym właśnie momencie ujawnia się czasowy rozdźwięk między pozaczasową perspektywą podmiotu-poety a punktem odniesienia, w postaci wytworów rąk ludzkich, natury oraz uczestników procesji, czyli - najogólniej mówiąc społeczności. Podmiot funkcjonuje poza cyklicznością i upływem czasu, ale pamięć o nim istnieje dzięki tradycji, z jej powtarzalnymi rytuałami.

Co ciekawe, motyw oddzielenia od społeczności nie jest zarysowany tak mocno jak w wypadku ody I, 1 czy III, 1 Odi profanum volgus. Dzieje się tak nie tylko dlatego, że nieśmiertelność twórcy jest ściśle związana z łańcuchem przekazywania pamięci, ale także ponieważ oda III, 30 nie dotyczy 
aktu twórczego, w formie porwania przez bóstwo i próby opanowania poetyckiego szaleństwa, lecz trwania dzieła ukończonego.

W ten sposób tekst zatacza kolejne koło, od exegi, czyli dokonaności czasu przeszłego, poprzez iteratywność i niedokonaność punktów odniesienia, do ostatecznej perfektywności frazy dicar deduxisse, w której orzeczenie w czasie przyszłym wydaje się jedynie potwierdzać trwałość poetyckich dokonań podmiotu. Jeżeli zatem, jak ukazał to Bohdan Chernyukh, akcentując funkcję „ograniczającą" (limitavity) perfectum, czas ten zawsze w podstawowym znaczeniu określa wydarzenie zakończone, bez względu na szerszy kontekst i klasę orzeczenia, fraza dicar deduxisse nawet na poziomie języka odnosi się do przełamania ograniczenia czasu, nawet gramatycznego (250).

Pomimo że między exegi monumentum a carmen deduxisse zachodzi oczywista analogia i na pewnym poziomie są tym samym, to jednak należy stwierdzić, że wyswobodzony z cykliczności podmiot-poeta nie jest już taki sam. Zaczynając bowiem jako twórca dumny z ukończonego dzieła, obecnie trwa jako nieśmiertelne bóstwo własnej poezji. Aby ukazać ten fenomen w kontekście literackim, należy odwołać się do, wyżej omawianych, toposu spotkania $\mathrm{z}$ bóstwem oraz motywu porwania przez bóstwo, a także figury pochodu tanecznego, która na poziomie poetyckiego obrazowania, łącznie z motywem locus amoenus, staje się podstawą konstrukcji granicznej przestrzeni, w jakiej funkcjonuje powyższa topika, $\mathrm{z}$ centralnym punktem $\mathrm{w}$ postaci figury odautorskiego podmiotu-poety.

Jednym z wciąż tajemniczych elementów ody III, 30 jest bowiem motyw pochodu kapłana $z$ westalką na Kapitol oraz jego funkcja w ukazaniu pozycji podmiotu. Nisbet i Rudd, przywołując szereg interpretacji badaczy, którzy byli skłonni widzieć w odzie obraz pochodu triumfalnego, z podmiotem w roli triumfatora, jednocześnie odrzucają tę interpretację ze względu na tematykę utworu, różnicę $\mathrm{w}$ rozumieniu symboliki pochodu triumfalnego (szczególnie rola wieńca) i brak fundamentalnego motywu zwycięstwa oraz formalnej struktury pompa triumphalis (376). I chociaż wątpliwości badaczy są słuszne, nie można zaprzeczyć, że Horacy nawiązywał do formy procesji, analogia zaś między pochodem kapłana i westalki a „pochodem podmiotu i pieśni” jest zbyt istotna, by zupełnie ją pominąć. Ritus jednak w tym wypadku nie musi odwoływać się do obrazu pompa triumphalis, ale do pochodu znacznie bliższego poezji - pochodu chóralnego (korowodu).

Ten obraz w poezji Wenuzyjczyka należy oderwać od typowo bakchicznego lub typowo apollińskiego rozumienia, gdyż taki podział w obrębie już w pełni Horacjańskiej koncepcji przestaje obowiązywać, został bowiem 
zastąpiony eklektycznym konsensusem, świadomym poetyckim połączeniem żywiołów. W obrębie ody III, 30 następuje drugie symboliczne połączenie żywiołu greckiego (carmen Aeolium ${ }^{2}$ ) z italskim. Obraz poetycki ody III, 30 byłby zatem bliższy pochodowi nowego bóstwa, szerzącego na danym terenie nową religię, niż triumfalnemu pochodowi wodza.

Pozycję podmiotu ustala napięcie między potens i princeps, kolejno na końcu 12 i początku 13 wersu, które wraz z motywem pochodu - carmen deduxisse - tworzy obraz przypominający pochód Bakchusa w odzie III, 25, 14-20 (por. Eur. Ba. 13-22). W tej pieśni Bakchus (jako potens - władca, „ten, który panuje nad kimś”) prowadzi niepowstrzymany pochód Najad i Bakchantek, a za nim w tymże pochodzie kroczy sam podmiot (sequi deum w. 19), którego szczególna pozycja wynika z uwieńczenia przez samo bóstwo (w.20) (Nisbet i Rudd 308-309). O ile zatem w odzie III, 25 podmiot-twórca szedł za Bakchusem, naśladując go w poetyckim pochodzie poprzez sięgnięcie po boskie artefakty, o tyle już w pieśni III, 30 zmienia pozycję i wysuwa się na początek takiego pochodu jako princeps - protagonista, który słusznie domaga się oficjalnej poetyckiej koronacji od Muzy.

W tym wypadku potens to znacznie więcej niż dux czy nawet imperator. $\mathrm{W}$ takiej bowiem konfiguracji podmiot jawi się, co najmniej, jako oikistes

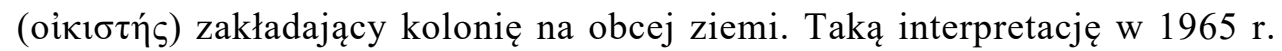
zaproponował Egon Maróti, opierając się na techniczno-terminologicznym znaczeniu deducere $\mathrm{w}$ złożeniu coloniam deducere. Badacz odniósł się przede wszystkim do kontekstów socjologiczno-militarnych, powołując się na Eneidę i rolę Eneasza jako przywódcy ocalonych Trojan i założyciela kolonii na nowej ziemi, a także na biografistykę (Swetoniusz), zapisy prawne i techniczne (szczególnie Cycerona), w których deducere pojawia się, jak można wywnioskować z artykułu, w znaczeniu ,przeprowadzić kogoś skądś dokądś w celu pozostania na danym terenie (założenia kolonii, miasta)" (101 nn.). Chociaż argumentacja badacza zbytnio oddala się od samej poezji i bliższych jej obrazów, nie zmienia to jednak faktu, że usytuowanie podmiotu

\footnotetext{
${ }^{2} \mathrm{~W}$ niniejszym artykule przyjęto konieczne uproszczenie, fraza carmen Aeolium wskazuje jednak na Horacjański model poetyckiej imitacji greckich poetów archaicznych (zwłaszcza Alkajosa; Nisbet i Rudd 375) jako istotnej części jego programu poetyckiego (por. Hor. Carm. IV, 3, 12). To zagadnienie wpisuje się w znacznie szerszą problematykę nowego modelu literatury w okresie augustowskim, opartego na wzorcach klasycznych i archaicznych. Powrót do literatury „dawnej” wynikał nie tylko ze sporu z aleksandrynizmem neoteryków (zdobycze poezji uczonej i technicznie doskonałej okazały się trwałe), ale przede wszystkim z poszukiwań modelu właściwego do wyrażenia ważkich treści - religijnych, społecznych i politycznych - w nowej epoce, do czego nie była zdolna formuła literackich nugae (zob. Atkins 47-54; Hor. Ars 319-322).
} 
w roli oikistesa, fundatora kolonii, któremu należy się niemal boska cześć i miejsce w świątyni doskonale wpisuje się w sytuację liryczną.

Egon Maróti twierdził, że kluczem do zrozumienia analizowanego fragmentu ody III, 30 jest deduxisse (101). Zgadzając się z tym, można jednocześnie wzbogacić znaczenie deducere odniesieniem do stricte poetyckiego wyrażenia: ducere choros, które w twórczości Horacego pojawia się w odach I, 4 (w. 5) i IV, 7 (w. 6). W obydwu wypadkach konstrukcja jest identyczna - protagonista prowadzi grupę, która porusza się $\mathrm{W}$ określony sposób. W odzie I, 4, 5-8 jest to Wenus:

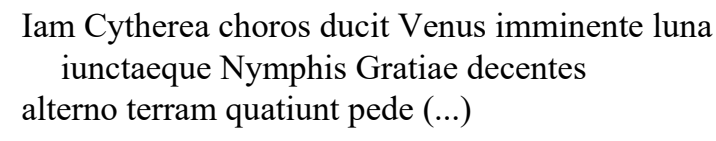

natomiast w odzie IV, 7, 5-6 jest to jedna z Gracji:

Gratia cum Nymphis geminisque sororibus audet ducere nuda chorus.

W przywołanych odach chorus pojawia się metaforycznie, stanowiąc określenie czasu, a ulokowany jest w początkowej fazie cyklu przyrody, w momencie, gdy znika śnieg, a łąki zaczynają zielenić się pierwszą trawą w rytm tańca bóstw przyrody i Wenus w funkcji bóstwa płodności, co nawiasem mówiąc przypomina pochód Afrodyty z V Hymnu homeryckiego (68-75). Należy jednak podkreślić, że tak pojęty motyw nie oznacza wprost „przyrody budzącej się do życia", nie wskazuje na triumf życia nad śmiercią, lecz jedynie na początek nowego cyklu. Obydwie ody rozpoczynają się bowiem od wspomnienia o stopniałym śniegu, a chorus stanowi coś, co łączy i rozdziela początek i koniec cyklu. Motywy te są zatem jedynie elementem Horacjańskiego toposu carpe diem, wstępem do rozważań nad naturą i konsekwencjami ludzkiej śmiertelności. Towarzysząca zaś im euforia odrodzenia jest jedynie kontrapunktem dla nieuchronności śmierci.

Jeżeli zatem przyjąć, że rytuał pochodu na Kapitol w obrębie tekstu staje się figurą pamięci (Assman 53-58, 72-74), z którą zrasta się pamięć o poecie - nie tyle na zasadzie postaci czczonej w rytuale, ale postaci, która ukształtowała rytuał, tak jak sam Horacy ukształtował rzymską kulturę, jak ukształtował pamięć o ubóstwionych władcach (a więc jego formę i treść), wówczas pojawia się pytanie o kształt tego rytuału - o jego figurę w obrębie tekstu. Wydaje się, że został on zobrazowany na wzór chorosu, poprzez specyficzne wykorzystanie czasownika scandere. 
W podstawowym znaczeniu słowo to oznacza poruszanie się wzwyż, wchodzenie na coś, przy czym, bazując na słownikach, można odnieść wrażenie, że częstokroć było używane w kontekstach militarnych (Lewis i Short 1639; Glare 1699; Hor. Carm. II, 19, 22; Liv. III, 68, 7; V, 21, 12). W wypadku jednak ody III, 30 należy podkreślić jego użycie przenośne, które oznaczało specyficzną formę ruchu, polegającą na dzieleniu danej przestrzeni na odcinki: „Vox (...) altitudinem gradatim scandit” (Vitr. V, 3, 7); „paulatimque gradus aetatis scandere adultae” (Lucr. II, 1123). Znaczenie ukazuje się w derywacie scalae (drabina, schody; Vaan 542). Ten wymiar jest zakorzeniony $\mathrm{w}$ protoindoeuropejskim *skend-, wiązanym ze „skakaniem" (Walde 684; Vaan 543; LIV, 554.1). Potencjał tego słowa w wyrażaniu rytmu i miarowości można ukazać na przykładzie związku frazeologicznego scandere versus, należącego do języka gramatyków łacińskich przynajmniej od czasów Terencjana Maura, około 200 n.e. (Maur. 547; $1465 ; 1753$; również w kolokacji scandere versus pedibus, scandere pentametrum). Jego znaczenie opierało się na metaforycznym nawiązaniu do ruchów podnoszonej i opuszczanej stopy, wybijającej rytm metrum (Ernout i Meillet 599).

Trudno oczywiście byłoby łączyć wprost obrazy tańca i pochodu kapłana, ale należy podkreślić, że w obydwóch przypadkach pojawia się bardzo podobny mechanizm wyznaczenia rytmu, oparty o miarowe uderzanie stopa o ziemię. W pierwszym wypadku oznacza to ukazanie wprost osób w tańcu, w drugim można mówić o kontekście metaforycznym, nieobcym jednak Horacjańskiej zasadzie junktury (Ars $46 \mathrm{nn}$.).

Nie chodzi oczywiście o stwierdzenie, że kapłan wstępuje na Kapitol tanecznym krokiem, byłoby to sprowadzeniem tego motywu do absurdu, lecz o podkreślenie miarowości tego kroku, odpowiadającej harmonijnie motywowi wprowadzania przez podmiot miar eolskich do nie w pełni ukształtowanych rytmów czy melodii poezji rzymskiej (zob. Nisbet i Rudd 375; por. także Hor. Epist. II, 1, 156-157: „Graecia ... artes / intulit agresti Latio”). Wraz z cyklicznością czasu odmierzanego powtarzalnością rytuału podkreśla to ich wszechobecność i zakorzenienie w ukształtowanych przez podmiot-poetę kulturowych formach pamięci - do tego stopnia, że odseparowanie poety, jego dokonań i danej kultury nie jest już możliwe, a ich współzależność prowadzi do utożsamienia. 


\section{K $\Omega$ MO $\Sigma$ I XOPO $\Sigma-$ PODSUMOWANIE}

Biorąc pod uwagę istotę poezji dionizyjskiej, która polegała na współgraniu słowa, dźwięku i ruchu (tańca, gestu) (Rothwell 6), należy postawić pytanie o tworzony przez Horacego obraz korowodu.

Objaśniając łaciński rzeczownik chorus, Charlton Lewis i Charles Short

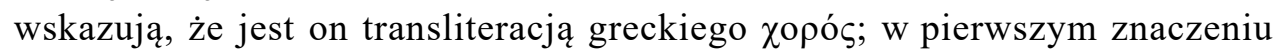
odsyłają czytelnika wprost do greckiego słownika Henryego Liddella i Roberta Scotta (Lewis i Short 328; Glare 311; Liddell i Scott 1735). Taka adekwatność nie budzi wątpliwości, niemniej u Horacego słowo chorus wystę-

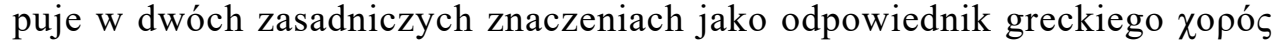
w sensie terminu technicznego na oznaczenie specyficznej formy tańca oraz na oznaczenie grupy powiązanych ze sobą ludzi. W takim znaczeniu występuje w odzie IV, 3 Quem tu, Melpomene na określenie grupy wieszczów (w. 14-15): ,dignatur suboles inter amabilis / vatum ponere me choros” (por. Hor. Carm. I, 1, 35). Podobnie w odzie IV, 14, 21-22 chorus określa Plejady (ze względu również na ich kolisty ruch po sklepieniu): „exercet Auster Pleiadum choro / scindente nubes".

Podstawowe jednak znaczenie uwydatniają wspomniane już ody I, 4 oraz IV, 7. Obrazy w nich konstruowane nawiązują do konwencjonalnych przedstawień postaci tańczących w kole, które poruszają się w określonym rytmie: $\chi 0-$

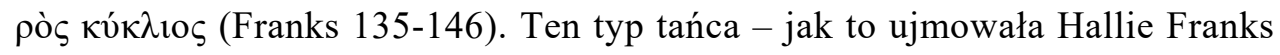
- stanowił idealną metaforę stałego, cyklicznego ruchu Kosmosu (136).

Należy zaznaczyć, że nie jest to jedyna forma pochodu tanecznego obecna w twórczości Horacego. Kolejną jest pochód biesiadny, powiązany

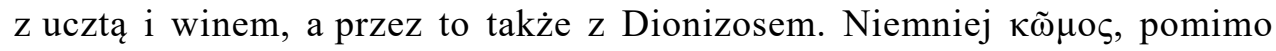
częstego występowania w poezji, ma inną wartość semantyczną w obrębie literatury; owa odrębność jest widoczna także w odach.

W języku łacińskim trudno odnaleźć adekwatny termin określający grecki $\kappa \tilde{\omega} \mu$ os. Słownik Liddella i Scotta podaje przy tym haśle łaciński odpowiednik - comessatio, co można wyprowadzić od comedere, odnoszącego się do wspólnego ucztowania. Brak pełnej adekwatności wynika zapewne z różnic kulturowych, sympozjon grecki nie miał dokładnego odpowiednika w kulturze rzymskiej (przynajmniej nie we wczesnym okresie). Nie znaczy to, że nie było sposobu na wprowadzenie tego zjawiska do rzymskiej literatury.

Horacy ekwiwalent kulturowy odnalazł w tanecznych pochodach Saliów przywołanych w odzie I, 36, 10-12: 


\section{Cressa ne careat pulchra dies nota neu promptae modus amphorae neu morem in Salium sit requies pedum}

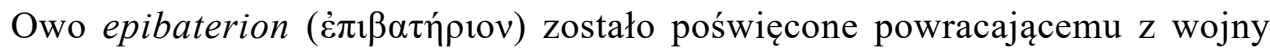
przyjacielowi, witanemu ucztą, a samo porównanie do „zwyczaju Saliów” według Porfiriona - oznacza intensywne „picie i tańczenie” (140). Podobny motyw pojawia się w odzie I, 37, pieśni triumfalnej po zwycięstwie pod Akcjum (w. 1-4):

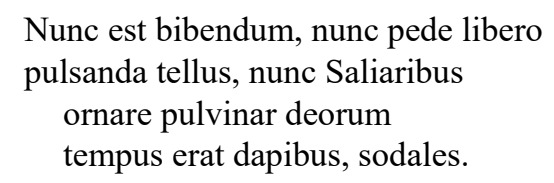

O ile jednak nawiązanie do pompa circensis czy ogólnie do rytuałów tańca $\mathrm{z}$ bronią kontekstualnie wiąże się z militarną tematyką przywołanych tekstów, nie można go odnieść wprost do thiasos Bakchusa. Dodatkowo, pomimo że motyw tańca i jego opis: „pede (...) pulsanda tellus” jest taki sam jak w wypadku określenia chorus, problemy rodzi interpretacja konkretnych przedstawień tego typu w kulturze rzymskiej (Fless i Moede 253259), a co za tym idzie - sposób postrzegania starożytnych rytuałów przez „Lukańczyka czy Apulczyka” Horacego. Mimo to warte podkreślenia jest, że „muzyka i taniec są centralnymi elementami rzymskich rytuałów religijnych" (1).

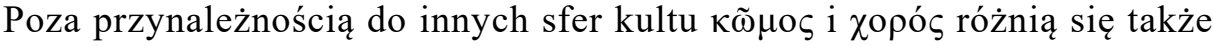
stopniem „realizmu”. Nie tyle jednak w zakresie weryfikacji prawda-fałsz, ale raczej w zakresie specyficznych sposobów tworzenia znaczeń.

John Landels, badając malarstwo wazowe, zaznaczył, że owej różnicy można się dopatrywać właśnie w poziomie realności. Otóż $\kappa \tilde{\omega} \mu \circ \varsigma$ jako pochód ucztujących lub pochód orszaku Dionizosa był przedstawiany jako coś prawdziwego - realni byli biesiadnicy, realne były Nimfy i prawdziwi

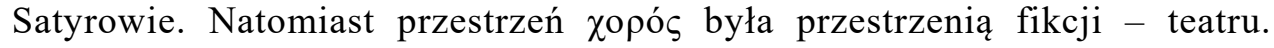

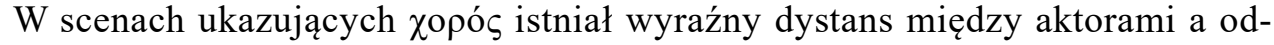
grywanymi przez nich postaciami, zaznaczony poprzez obecność masek i innych rekwizytów (Landels 66). Wprowadzał on zatem element fikcyjny, teatralny, literacki - dystans między rzeczywistością a naśladownictwem.

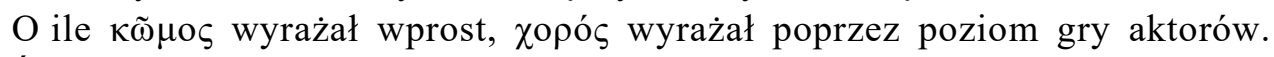
Świadomość tej odrębności rzeczywistości i przestrzeni teatralnej znakomicie przedstawia słynna waza Pronomosa, ukazując aktorów w różnych 
stadiach przygotowywania się do gry (Landels 22; Robertson 255-264).

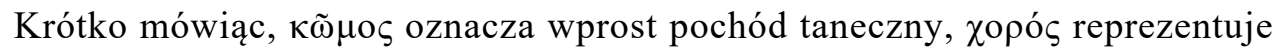
coś naddanego.

Podobną dwoistość można zauważyć w przytoczonych w artykule pieśniach. Z jednej strony znalazłyby się ody I, 1; III, 4; III, 25, których tematyka konstytuuje treści metaliterackie, z drugiej I, 36 i I, 37. W epibaterion i odzie „triumfalnej” w tańczących można byłoby postrzegać postaci występujące w tekście, które reprezentowałby same siebie; w metatekstach obraz na pierwszym poziomie odsyłałby do sceny bakchicznego thiasos, który z kolei byłby znakiem odsyłającym do języka dyskursu literackiego - do mantyki, natchnienia, ingenium, amabilis insania.

W wypadku ody III, 30 postawienie takiej granicy jest w zasadzie niemożliwe; poeta, odwołując się do rytuałów tanecznych, tak mocno zagęścił ich funkcje i tak bardzo zmieszał kulturowe odniesienia, że spoiły się one w jeden indywidualny i funkcjonalny motyw, organizujący tekst konkretnej pieśni.

Obraz pochodu jest nieostry, ponieważ tradycja została dostosowana do indywidualnej wizji, przeformułowana w symbolikę Horacjańską, czerpiącą z przeszłości i kultury, ale niekoniecznie wprost ją naśladującą. Trudność wynika także z jego podwójności, która jest konsekwencją wspominanego powyżej współistnienia dwóch przestrzeni i dwóch czasów w obrębie ody czasu cyklicznego i przestrzeni śmiertelnych uczestników pochodu oraz bezczasu i przestrzeni liminalnej, w jakich istnieje nieśmiertelny wieszcz. Można zatem powiedzieć, z braku osobnych terminów posługując się okre-

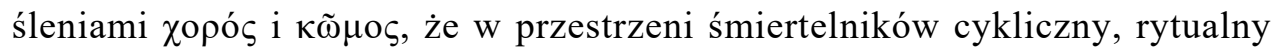

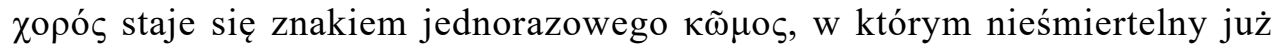
podmiot-poeta ukonstytuował rzymską lirykę.

Widoczne jest to w sposobie realizacji motywu pochodu. Jako pierwsza została ukazana zewnętrzna forma oraz funkcja figury pamięci - pochód kapłana. Czerpiąc z metaforycznych możliwości tańca w kole, odsyła on do cykliczności oraz wprowadza poziom reprezentacji, a co za tym idzie - im-

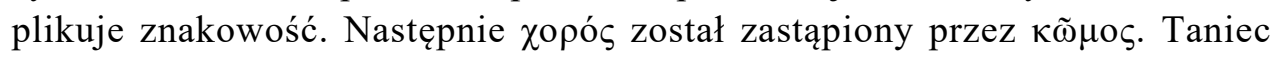
w kole ustąpił pochodowi tanecznemu, wyrażającemu treść figury pamięci dokonanie w postaci wprowadzenia miar eolskich, dopełniając w ten sposób relację między znakiem a desygnatem; faktem a sposobem jego upamiętnienia. Ale semantyka motywu nie wyczerpuje się w tej syntezie, ponieważ upamiętnienie dokonań jednostki w formie ritus nadaje tejże jednostce specjalny status. Motyw pochodu przemienia się w motyw przejścia $-\mathrm{z}$ Eolii do Italii w metaforycznej przestrzeni literackiej; od życia do śmierci i, poprzez 
pamięć, do nieśmiertelności w sytuacji lirycznej ody; od człowieczeństwa do ubóstwienia w figurze podmiotu lirycznego. Owo przejście, jednolity fenomen, realizujący się w dwóch aspektach - czasowym i przestrzennym, można ukazać $\mathrm{w}$ kontekście toposu spotkania z bóstwem jako jego przeformułowanie, polegające na usytuowaniu poety, wybitnego przedstawiciela danego gatunku literackiego, w miejscu bóstwa. W ten sposób pomiędzy odą I, 1 a odą III, 30 została dopełniona Horacjańska figura wieszcza. Jej zaś funkcja i znaczenie porównywalne są z rolą postaci „Anakreonta” $\mathrm{w}$ fenomenie poezji anakreontejskiej jako „bóstwa opiekuńczego”, które udziela natchnienia i prawa do jej wykonywania.

Owa figura jest podstawą konstrukcji samoświadomego podmiotu-twórcy, który przekracza miarę wyznaczoną śmiertelnikowi, co zostało dobitnie podkreślone w ostatnich wersach pieśni. Antyczny twórca w takiej konstrukcji mógł odwołać się do swego rodzaju ubóstwienia wybitnego poety czy filozofa, jakie można obserwować na gruncie literackim. W takim wypadku ów ubóstwiony poeta, prawodawca gatunku, funkcjonował jako bóstwo opiekuńcze, zsyłające natchnienie $\mathrm{w}$ danej dziedzinie. Z pogranicza filozofii i poezji można przywołać proces heroizacji Epikura w De rerum natura Lukrecjusza (Lucr. I, 62-79). Jeszcze lepszym przykładem jest postać ubóstwionego Homera, który ukazuje się we śnie Enniuszowi i w wędrówce dusz wciela się w niego, obdarzając go talentem poetyckim (Hor. Epist. II, 1, 50-52). Owo zjawisko zostało zaczerpnięte z gruntu greckiego, gdzie można wskazać tradycję anakreontyków, w których anonimowi twórcy spotykają, obdarzającego ich talentem i wiedzą, Anakreonta (Carm. Anacr. 1 W, 1-3, 11-17). Tego typu spotkania, obejmujące również spotkanie ze zgryźliwą staruszką Jambe u Hipponaksa, Tomasz Mojsik interpretuje jako wersję toposu spotkania z bóstwem (234-240, 243). Horacy nawiązywał do niej w epodach 8 i 12, poświęconych zgryźliwym i rozpasanym dojrzałym kobietom, $\mathrm{z}$ którymi podmiot rozmawiał w konwencji jambicznej.

W pieśniach Horacego ów motyw jednak występuje w tradycyjnym kształcie - w postaci spotkania z bóstwem, nie zaś ubóstwionym przedstawicielem gatunku, ponieważ - inaczej niż w satyrze, w której mistrzostwo, mimo krytyki, pozostawił Lucyliuszowi - na gruncie liryki łacińskiej sam postanowił zająć to miejsce. Uderzająca jest w tym kontekście figura poety-pszczoły w czwartej księdze ód, która z jednej strony nie stanowi rywalizacji z łabędziem Pindara, ale z drugiej należy pamiętać, że to właśnie pszczoły, według legendy, złożyły na ustach Pindara miód, co było początkiem jego twórczości. Powiązane były także ze sferą Muz i kunsztem poetyckim (Mojsik 
240). Również w odach IV, 2 Pindarum quisquis czy IV, 9 Ne forte credas, w których występuje cała plejada wielkich poetów antyku, kwiatów, z których pracowita pszczoła zbiera nektar swojej poezji: Pindar, Homer, Alkajos, Stesichoros, Anakreont, Safona, funkcjonują także nawiązania do tragedii, obejmujące triadę wielkich tragików (Woodman 53-64), wciąż brak toposu spotkania $\mathrm{z}$ bóstwem gatunku, w postaci konkretnego twórcy. I nawet jeżeli oda IV, 2 w pewien sposób niweluje szumną transformację w łabędzia-Pindara z ody II, 20, poprzez wskazanie na upadek Ikara, którego przerosły skrzydła, to wciąż stanowi ona współzawodnictwo dojrzałego poety $\mathrm{z}$ równym mu twórcą (aemulari), nie zaś naśladownictwo ucznia (imitari). Można więc mówić o zwycięstwie własnej wizji twórczości nad wzorcem.

Topos spotkania z bóstwem ewoluuje zatem w twórczości Horacego od quasi-religijnego, magicznego i inicjacyjnego spotkania z Muzami, poprzez apolliński motyw przemiany $\mathrm{w}$ łabędzie (vates biformis), pominięty ze względu na ramy artykułu, oraz bakchiczny - porwania przez bóstwo, aż do ustanowienia prawodawcy gatunku i ubóstwienia samego poety. W tej przemianie toposu figura poety stopniowo przesuwa się ku przodowi pochodu najpierw będąc jego uczestnikiem, następnie kapłanem idącym w ślad za bóstwem, a następnie przodownikiem. Ta figura w czwartej księdze ód zyska również swój „epilog” w postaci poety-didaskalosa, podmiotu w roli nauczyciela (Carm. IV , 2, IV, 6 i IV, 9). Jest to istotne osiągnięcie sztuki Horacego, gdyż, można powiedzieć, kontynuuje rolę moralisty z Satyr i zyskuje autorytet $\mathrm{w}$ zakresie sztuki poetyckiej, który stanowi podstawę kreacji podmiotu-krytyka w listach poetyckich. Czwarta księga ód, powstająca mniej więcej równolegle $\mathrm{z}$ listami, dopełnia transformację z poety początkującego $\mathrm{w}$ poetę ubóstwionego, bóstwo własnej koncepcji lirycznej, które stoi na pozycji muzy, udzielającej natchnienia, lub nauczyciela, udzielającego lekcji sztuki, w Horacjańskiej syntezie ars i ingenium.

Nim jednak zostanie ona w pełni sformułowana w Sztuce poetyckiej (Ars 408-411), na gruncie liryki łacińskiej Horacy stworzy symbiozę, jaka zachodzi między danym gatunkiem a jej wybitnym przedstawicielem, także między poetą Rzymu a samym Rzymem, kiedy jedno staje się gwarantem istnienia drugiego.

Podmiot nie posługuje się naturalnie terminem divus ani nie uzurpuje sobie miejsca zarezerwowanego dla władcy, ale posiadając moc ubóstwienia człowieka, staje się prawodawcą rytuału i w tym ograniczonym zakresie jest oikistesem swojego własnego świata. W nim odbiera zasłużoną cześć. W nim gromadzi współczesnych uczestników starożytnego ritus. 


\section{BIBLIOGRAFIA}

Assmann, Jan. Pamięć Kulturowa: Pismo, zapamiętywanie i polityczna tożsamość w cywilizacjach starożytnych. Thum. Anna Kryczyńska-Pham. Wyd. 2, Wydawnictwa Uniwersytetu Warszawskiego, 2020.

Atkins, John William Hey. Literary Criticism in Antiquity: A Sketch of Its Development. Volume 1-2 Graeco-Roman. Cambridge University Press, 1934.

Bakuła, Bogusław. Człowiek jako dzieło sztuki: z problemów metarefleksji artystycznej. Wydawnictwo WiS, 1994.

Bernhard, Maria Ludwika. Historia Starożytnej Sztuki Greckiej. Wyd. 3, Państwowe Wydawnictwo Naukowe, 1991.

Bonnechere, Pierre. „Divination.” Companion to Greek Religion, red. Daniel Ogden, Blackwell, 2006, ss. 145-59.

Brink, Charles Oscar. Horace on Poetry: Prolegomena to the Literary Epistles. Vol. 1. Cambridge University Press, 1963.

Brink, Charles Oscar. Horace on Poetry: The Ars Poetica. Vol. 2. Cambridge University Press, 1971.

Burkert, Walter. Starożytne Kulty Misteryjne. Tłum. Krzysztof Bielawski, Homini, 2001.

Chernyukh, Bohdan. „The Perfect and Semantics of Perfectivity in Latin.” Meridian Critic, t. 28, nr 1, 2017, ss. 245-251.

Danielewicz, Jerzy. „Semantyczne funkcje form metrycznych w poezji antycznej”. Pamiętnik Literacki, t. 74, nr 1, 1983, ss. 123-135.

Danielewicz, Jerzy. „Metatext and Its Functions in Greek Lyric Poetry”. Texts, Ideas, and the Classics: Scholarship, Theory, and Classical Literature, red. Stephen John Harrison, Oxford University Press, 2007, ss. 46-62.

Devine, Andrew M., i Laurence D. Stephens. Semantics for Latin: An Introduction. Oxford University Press, 2013.

Embick, David. „Features, Syntax, and Categories in the Latin Perfect”. Linguistic Inquiry, t. 31, nr 2, 2000, ss. 185-230.

Fantham, Elaine. Roman Literary Culture. John Hopkins University Press, 1996.

Fless, Friederike, i Katja Moede. „Music and Dance: Forms of Representation in Pictorial and Written Sources". A Companion to Roman Religion, red. Jörg Rüpke, Blackwell, 2007, ss. 249-262.

Gardin Dumesnil, Jean Baptiste, i J.M. Gosset. Latin Synonyms, with Their Different Significations, and Examples Taken Form the Best Latin Authors. London 1809.

Glare Peter G. et al., editors. Oxford Latin Dictionary: 1. Clarendon Press, 1968.

Günther, Hans-Christian. „The First Collection of Odes: Carmina I-III.” Brill's Companion to Horace, red. Hans-Christian Günther, Brill, 2014, ss. 211-406.

Harrison, Stephen John. Texts, Ideas, and the Classics: Scholarship, Theory, and Classical Literature, red. Stephen John Harrison. Oxford University Press, 2007.

Helenius, Acro, Porphyrio Pomponius, and Ferdinand Hauthal. Acronis Et Porphyrionis Commentarii in Q. Horatium Flaccum. Sumptibus J. Springeri, 1864.

Horatius Flaccus, Quintus. Quinti Horati Flacci opera omnia, red. and Oktawiusz Jurewicz, Ossolineum, 1986. 
Knapp, Charles. „The Originality of Latin Literature.” The Classical Journal, t. 3, nr 7, 1908, ss. 251-60.

Knapp, Charles. „The Originality of Latin Literature II.” The Classical Journal, t. 3, nr 8, 1908, ss. 299-307.

Kühner, Raphael. Ausführliche Grammatik Der Lateinischen Sprache: 1. Gottschalk, 1955.

Landels, John G. Music in Ancient Greece and Rome. Digital print. Routledge, 2002.

Liddell, Henry George, i Robert Scott, redaktorzy. Greek-English Lexicon. New York 1883.

Maisonneuve, Jean. Rytuały: dawne i wspótczesne. Tłum. Marta Mroczek, Gdańskie Wydawnictwo Psychologiczne, 1995.

Maróti, Egon. „Princeps Aeolium carmen ad Italos deduxisse modos. Bemerkungen zur Interpretation von Horaz' Carm. III. 30, 13-14". Acta Antiqua Academiae Scientiarum Hungaricae, nr 13, 1965, ss. 97-109.

Moens, Mark, i Mark Steedman. “Temporal Ontology and Temporal Reference.” Computational Linguistics, t. 14, $\mathrm{nr}$ 2, 1988, ss. 15-28.

Mojsik, Tomasz. Antropologia metapoetyki: Muzy w kulturze greckiej od Homera do końca V w. p.n.e. Wydawnictwo Neriton, 2011.

Nisbet, Robin G.M. „The Word Order of Horace's Odes”. Proceedings of the British Academy, vol. 93, 1999, ss. 135-154.

Nisbet, Robin George Murdoch, i Margaret Hubbard. A Commentary on Horace: Odes, Book 1. Clarendon Press, 1970 [repr. 2001].

Nisbet, Robin G.M., i Niall Rudd. A Commentary on Horace, Odes: Book III. Clarendon, 2004.

Otis, Brooks. „The Uniqueness of Latin Literature”. Arion, t. 6, nr 2, 1967, ss. 185-206.

Pinkster, Harm. The Oxford Latin Syntax. Oxford University Press, 2015.

Prauscello, Lucia. „Sculpted Meanings, Talking Statues: Some Observations on Posidippus 142.

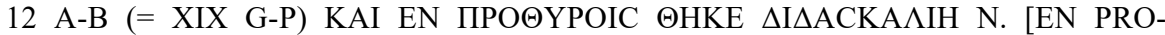
THYROIS THIKE DIDASKALII N]" The American Journal of Philology, t. 127, nr 4, 2006, ss. 511-523.

Q. Horati Flacci Opera, red. Fridericus Klingner, wyd. 3 [Editio Stereotypa editionis tertiae (MCMLIX)], De Gruyter, 2008.

Q. Horativs Flaccvs, Opera, red. David R. Shackleton Bailey [Editio Stereotypa editionis qvartae (MMI)], De Gruyter, 2008.

Robertson, Martin. The Art of Vase-Painting in Classical Athens. Cambridge University Press, 1996.

Rothwell, Kenneth Sprague. Nature, Culture and the Origins of Greek Comedy: A Study of Animal Choruses. Cambridge University Press, 2007.

Van Gennep, Arnold. Obrzędy przejścia. Systematyczne studium ceremonii. Tłum. Beata Biały, Państwowy Instytut Wydawniczy, 2006.

Wolanin, Hubert. Gramatyka opisowa klasycznej łaciny w ujęciu strukturalnym. Księgarnia Akademicka, 2015.

Woodman, Tony. „Biformis Vates: The Odes, Catullus and Greek Lyric”. Traditions and Contexts in the Poetry of Horace, red. Tony Woodman i Denis Feeney, Cambridge University Press, 2002, ss. 53-64.

Wypustek, Andrzej. „Motyw porwania przez bóstwo w greckich epigramach nagrobnych”. Spoteczeństwo i religia w świecie antycznym, red. Szymon Olszaniec i Przemysław Wojciechowski, Wydawnictwo Naukowe Uniwersytetu Mikołaja Kopernika, 2010, ss. 109-125. 
Żółkiewski, Stefan. „Przedmowa”. Semiotyka Kultury, red. Elżbieta Janus i Maria Renata Mayenowa, Państwowy Instytut Wydawniczy, 1977, ss. 5-64.

Żyłko, Bogusław. Semiotyka kultury: szkoła tartusko-moskiewska. Wydawnictwo Słowo/obraz terytoria, 2009.

\title{
„...DUM CAPITOLIUM SCANDET CUM TACITA VIRGINE PONTIFEX”. FUNKCJA FIGURY POCHODU W PIEŚNI III, 30 EXEGI MONUMENTUM HORACEGO
}

\author{
Streszczenie
}

Celem artykułu jest semiotyczna analiza motywu ,pochodu tanecznego" w Carm. III, 30 Exegi monumentum (w. 7-14) w perspektywie toposu spotkania z bóstwem w liryce Horacjańskiej, rozumianego jako forma rytuału przejścia. Autor poszukuje również odpowiedzi na pytanie, jaką funkcję pełni przywołany motyw w kompozycji tekstu oraz w ukształtowaniu figury podmiotu odautorskiego, ukazanego w roli ,poety” (vates). Postawiona problematyka wymagała odniesienia się do semiotycznej definicji tekstu oraz ujęcia toposu spotkania z bóstwem jako tekstu kultury. To z kolei wpłynęło na odniesienie się do badań antropologicznych (pojęcie rytuału) oraz kulturoznawczych ( $\kappa \tilde{\omega} \mu \circ \varsigma, \chi 0 \rho o ́ \varsigma)$, a także językoznawczych w zakresie semantyki i aspektu czasownika. Po przeprowadzonej analizie autor doszedł do wniosku, że motyw „pochodu tanecznego" w pieśni Exegi monumentum został ukazany dwufazowo jako cykliczny,

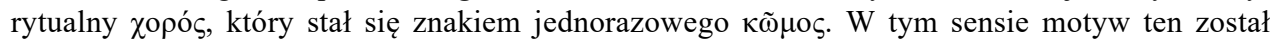
ukazany jako figura pamięci, odnosząca się do faktu połączenia przez Horacego miar eolskich z literaturą rzymską. W odpowiedzi na pytanie o konstrukcję podmiotu autor wskazał, że na bazie powyższej figury pamięci nastąpiło ubóstwienie wieszcza, który w przeformułowanym toposie spotkania z bóstwem zajmuje miejsce samego bóstwa, aspirując do roli analogicznej do figury „Anakreonta” w poezji anakreontejskiej (Carm. Anacr. 1 W, 1-3, 11-17).

Słowa kluczowe: metapoezja; semiotyka; rytuał przejścia; pochód taneczny; komos; chorus; figura pamięci.

\section{“...DUM CAPITOLIUM SCANDET CUM TACITA VIRGINE PONTIFEX”: THE FUNCTION OF THE FIGURE OF "PROCESSION" IN THE ODE III, 30 EXEGI MONUMENTUM OF HORACE}

\section{Su m m a ry}

This article contains a semiotic analysis of the "dancing procession" motif in Carm. III 30 Exegi monumentum (vv. 7-14) in the perspective of the topos of a meeting with a deity in the Horacian lyric, that was defined as a form of a rite of passage. The author also sought to answer the question of the function of the said motif in the composition of the text and in shaping the figure of the author's subject, shown as a "poet" (vates). The posed research problem required the use of a semiotic definition of the text and forced an approach to the topos of a meeting with a deity as a cultural text. Which, in turn, bear in on reference to anthropology (the concept of ritual) and cultural studies ( $\kappa \tilde{\omega} \mu о \varsigma, \chi о \rho o ́ \varsigma)$, as well as linguistics in terms of semantics and the aspect of a verb. After the analysis the author concluded that the "dancing procession" motif in the ode Exegi monumentum is shown in two phases as a cyclical, ritual $\chi 0 \rho$ ó $\zeta$, which became a sign of the 
one-time $\kappa \tilde{\omega} \mu \mathrm{o}$. In this sense, the motif was shown as a figure of memory, referring to the fact that Horace combined Aeolian meters with Roman literature. In reply to the question regarding the figure of the subject, the author indicated that on the basis of the above figure of memory the vates was deified and as such he took the place of the deity in the literary transformation of the topos of the meeting with a deity, aspiring to a role analogous to the figure of "Anacreont" in Anacreontic poetry.

Key words: Horace; metapoetry; semiotics; rite of passage; dancing procession; komos; chorus. 